$616.447: 616 \cdot 36$

上皮小體ノ病理組織學的研究

（第 2 報）

肝贜疾患二於ヶル上皮小體, 態度二就テ

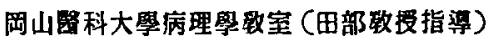

相 原 義 一

[昭和 8 年7月 4 日受稐]

Pathologisches Institut der Okay'ama med. Fokultäl

(Leiter: Prof. Dr. II. Tanabe).

\title{
Pathologisch-histologische Studien uber das Verhalten der Spithelkörperchen bei Lebererkrankungen.
}

Von

Giichi Aibara.

Eingegungen um 4. Juni 1933.

Verfasser stellte pathologisch-anatomische Untersuchungen dér Epithelkörpercheu (Epk.) an 35 menschlichen Leichen bei Lebererkrankungen, nämlich bei 18 Fällen von Leberzirrbose, 11 Fällen von Lebergeschwülsten, 4 Fällen von Leberabszess und 2 Fällen von Lebernekrose an und untersuchte ferner noch die Epk. bei 62 Fälen von Nichtlebererkrankungen zum Vergleich.

Zur Untersuchung der Grössen- und Gewichtsverhältuisse der Epk. wurden davon nur solche Fälle, bei welchen alle 4 Epk. vollkommen gefunden wurden, gervählt.

Die Epk. übertrafen durchschnittlich auffallend bei Lebererkrankungen sowobl an Gewicht als auch an Grösse die bei Nichtlebererkrankungen.

Histologisch zeigten die Epk. bei Lebererkrankungen einen kompakten Ball und meist eiu spärliches Interstitium. Was das Auftreten oxyphiler Zellen sowie des Kolloides anbetrifft, so konnte keine bestimmten Mengenverhältnisse konstatiert werden. Unter den Hauptzellen waren aber die hellen 7ellen bei Lebererkrankungen in der Mehrzahl der Fälle reichlicher vorhanden als die dunklen, während bei Nichtleber- 
erkrankungen in den meisten Fällen ein Überwiegen der dunklen Zellen festgestellt wurde. Da bei den Lebererkrankungen in einzelnen Fällen sogar Wucherungsherde der Hauptzellen nachgewiesen wurden, scheint es sich hier bei der Vergrösserung der Epk. im wesentlichen um eine Hyperplasie zu handeln.

Auf Grund obiger Untersuchungen kommt Verf. zu dem Schluss, dass bei einer Reibe von Lebererkrankungen, bei welchen das Leberparenchym in grossem Umfang geschädigt wird, in den Epithelkorperchen Wucherungserscheinungen vorkommen. Verf. fasst ferner die Hyperplasie der Epithelkörperchen wie das Überwiegen der hellen Hauptzellen als Ausdruck einer vermehrten Arbeitsleistung auf. (Attor eferat).

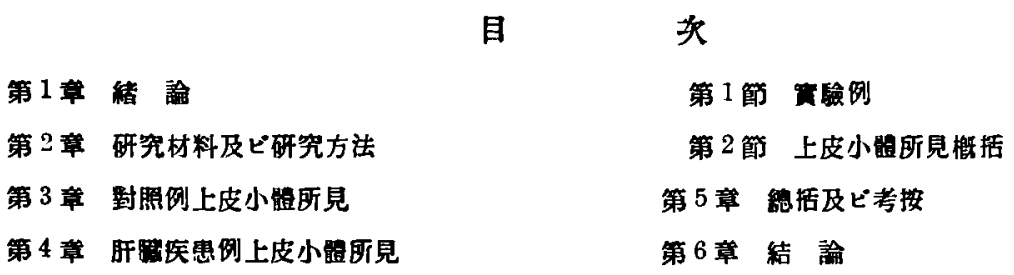

\section{第 1 章緒論}

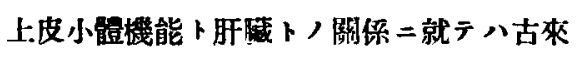

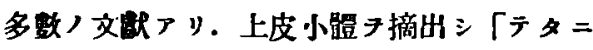

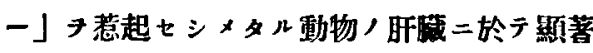
ナル脂肪阵フ認ムルコト八既二 Delitala, Harvier, Gozzi, Morel u. Rathery, Capobianco u. Mazziotti, Zanfrognini, Blum 等 ニョリ知ラレタリ. Underhill u. Blatherwick

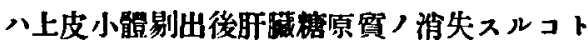
証 $\times$ 及 Carlson and Jacobson 八上皮小體

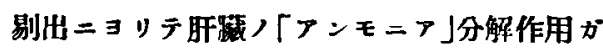
減退スト言とタレド，此恱八 Biedl, Winterberg, Albertoni, Greenwald, Medwedew 原等ニヨリ否定七ラレタリ。然レ共 Stoland 八上皮小體剔仙性「テタ二ー」二際三膽计成生 カ城退三䛈二䀥汁酸ノ減量スルコトタ云ヒ又 Wesselkin, Ssawitsch n. Ssudakawa 等八
犬二於とル賽駸二基キ上皮小體，缺損八膽计 分泌子減退七シメ尚木肝㖑, Aetherschwefelsäure 合成㙨能丹低下七シムルモノナリト 結諭シ，上皮小铻，譏能八牱臟，正嫦機能， 營篇二向ッテ重姴ナル關倸アルコトタ主張七 リ. 最近食八旰䧕, 有スル諸種, 機能二對三 上皮小體「ホルモン」ガ重大ナル菏節作用 7 有 スルコトフ證明セリ。

上皮小體ト旰裁トノ間二斯ク密接ナル開係 存在シ，，上皮小體八生理的若ク八将理的=肝

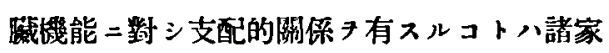

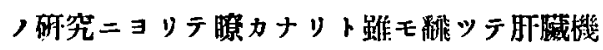
能障碍二際シ上皮小體が如何ナル留度キ示ス

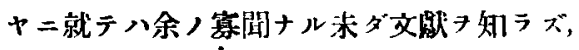

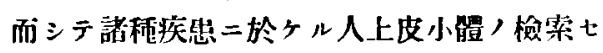
ラレタルモノ䬺シトセザルモ, 朋蔵疾出二於 
クル上皮小體ノ態度二關シテ八從來注意七ラ

レザリシトコロナリ．余八腎監疾患二於テ上

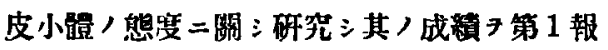

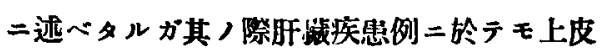
小體・展々腎眼疾患二於ヶルト類似スル所見
ヨ黛スルコト二氣附キタルナ以テ更二多數例

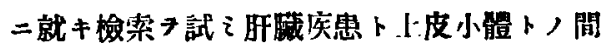
ニ一定ノ關保ノ存スルコトタ时力ニシ得タり 訨ツテ之ヨ茲二報告七ントス。

\section{第 2 章研究材料区研究方法}

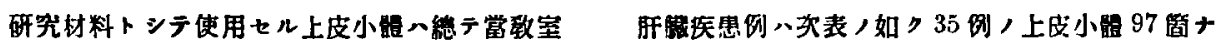

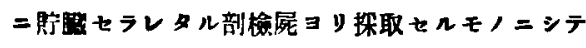

v.

第 1 表

\begin{tabular}{|c|c|c|c|c|c|}
\hline 病 & 器 & 别 & 洌 & 年 & 上皮小體旼 \\
\hline 訮 & 国硬 & 受 & 18 & $32-72$ 筬 & 50 \\
\hline 訮 & 踝 膿 & 湯 & 4 & $33-50$ 歲 & 10 \\
\hline 訮 & 䁃 棈 & 死 & 2 & $35-57$ 第 & 4 \\
\hline 肝 & 脿 腪 & 埸 & 11 & $35-73$ 蔵 & 33 \\
\hline
\end{tabular}

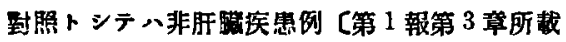

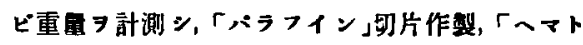
，到照 62 测 (6-78 藏)了，上皮小體 154 简 7 使 用セり。材料へくフォルマリン」固定ハママ大サ及 キシリン. エオジン」染色，van Gieson 氏架色 施シ又へ倲結切片トシ脂肪染色ョ施シテ检查せり。

\section{第 3 章 對照例上皮小铻所見}

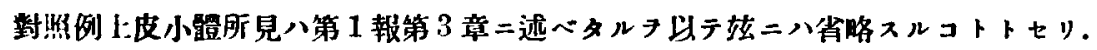

\section{第 4 章 肝甈疾愚例上皮小體所見}

\section{第 1 節 實驗例}

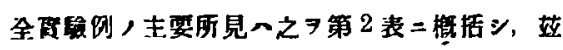

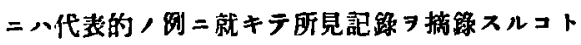
トセり.

\section{A 肝睡硬䭪则}

1. 第 1 侧 32 藏女

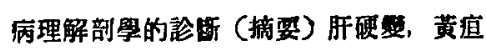

上皮小能所見 左上 $4.33 .22 .2 \mathrm{~mm} 20 \mathrm{mg}$ 左下 $4.3 \quad 3.3 \quad 1.2 \mathrm{~mm} \quad 7 \mathrm{mg}$

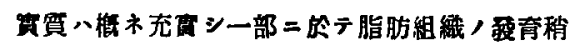

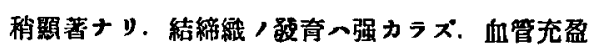

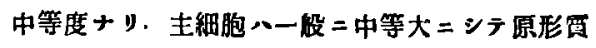

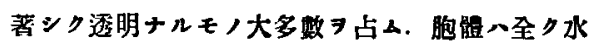
标透明ニシテ著シク距大セルモノ少カラズ．暗色 圭細胞ヘ少シ，且原形筫粗ナル顆籹狀 ノ多シ、㫮酸性細胞八個々散在性二僅二存在ス.

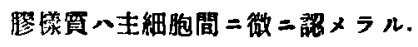




\section{2. 第 6 勋 43 歲 男}

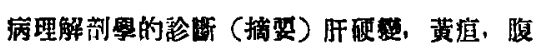
水

上皮小能所見 右上 $5.23 .71 .7 \mathrm{~mm} 16 \mathrm{mg}$ 右下 $6.3 \quad 2.0 \quad 0.9 \mathrm{~mm} 9 \mathrm{mg}$ 左上 $6.83 .01 .5 \mathrm{~mm} 19 \mathrm{mg}$ 左下 $6.13 .21 .2 \mathrm{~mm} 12 \mathrm{mg}$

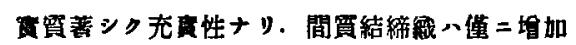

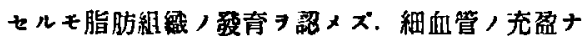
シ. 主細胞ハ著シク膨大シ全ク水想透明ニシテ砝

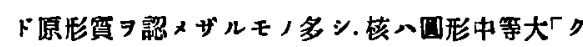
ロマチン」網稍く沄密ナリ、暗色主細胞ハ著シク 少ナリ旦原形䁈顆稙粗小ナリ、嘫酸生細胞・少数

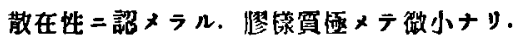

3. 第 14 例 55 茷女

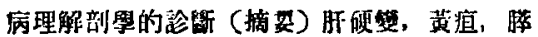
路滛

上皮小體所見 右上 $5.72 .80 .9 \mathrm{~mm} 60 \mathrm{mg}$ 在下 $4.41 .91 .5 \mathrm{~mm} 70 \mathrm{mg}$ 左上 $6.13 .11 .0 \mathrm{~mm} 90 \mathrm{mg}$ 左下 $4.82 .51 .7 \mathrm{~mm} 80 \mathrm{mg}$

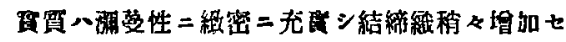
ルモ，脂肪細胞＼cjkstart訊メズ，血管僅 $=$ 充盈セリ．主細

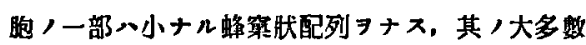
八选朋型細胞 ニシテ暗色主細胞八甚ダ僅少ナリ。 透明主細胞ハ主トシテ中等大ナルモ謷シク膨大セ 几モノ少カラメ2,3，細胞境界不明トナリ互二店

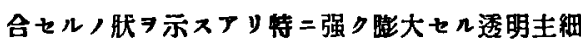
胞 ノミガ限局性二䗋究狀集在 $フ$ 示スモノフリ（附

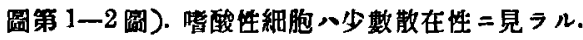

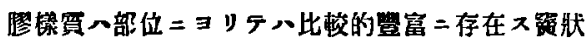
人胶 陵面 = 1 列二站ビ多量，含空胞性「エオジン」淡染

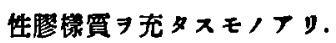

\section{B 肝腾摆埸四}

4. 第 22 䟝 50 歳 男

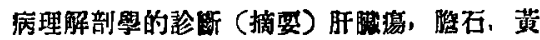
疸

上皮小能可見 右上 $5.73 .22 .3 \mathrm{~mm} 18 \mathrm{mg}$ 右下 $7.73 .71 .9 \mathrm{~mm} 29 \mathrm{mg}$ 灰上 $5.63 .3 \quad 2.0 \mathrm{~mm} 16 \mathrm{mg}$ 左下 $5.44 .62 .0 \mathrm{~nm} 24 \mathrm{mg}$

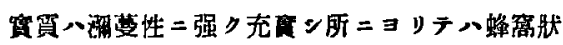

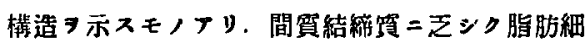

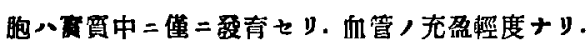
主細胞八過坐唀明主梱胞ナレトモ暗色主細胞モ可 成混在ス. 主細胞，盷體 左下上皮小䯏二於テ八周逗ノ一部分八限局性二結

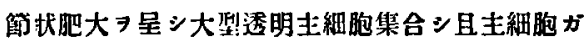
图杜形

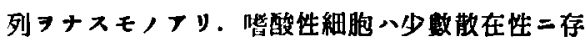

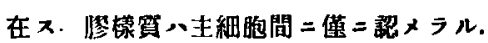

\section{O 肝甈死例 \\ 5. 第 24 侧 57 啙 男}

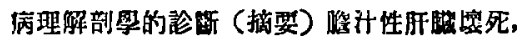

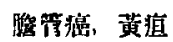
上皮小能所見 右上 $7.03 .71 .3 \mathrm{~mm} 21 \mathrm{mg}$ 左上 $7.03 .01 .5 \mathrm{~mm} 18 \mathrm{mg}$

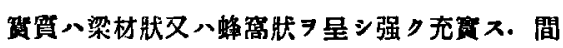

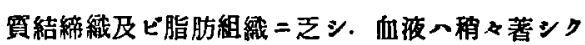
充盈ス. 主細胞八隐色透明兩細胞共二略ボ同程度 二出現 ス。晤色主細胞，原形貝顆粒八甚ダ粗小ナ リ. 兩細胞ハー般ニ混在スレドモ特二大型唀明主 細胞ノミガ著シク集在セルトコロフリ又唀明主細

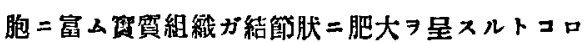

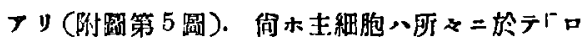

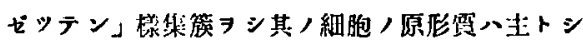
テ唀明ナレドモ一部ノ「ロゼッテン」ハ暗色細胞ヨ 
リ形成セラル. 斯ル「ロゼッテン」ガ特二多数群雀 シナス所フリ(附踹第 6 圖).

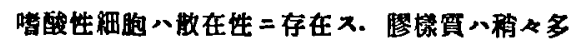
ク主細胞間 $=介$ 在 $x$.

\section{D 旰路嗹埸附}

6. 第 27 侧 40 战男

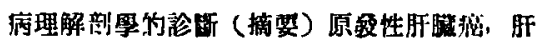

$$
\text { 「ヂストマ」寄生 }
$$

上芳小能所見 左上 $8.5 \quad 2.01 .3 \mathrm{~mm} \quad 15 \mathrm{mg}$

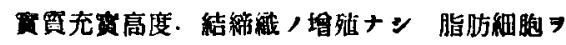

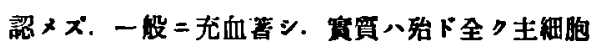

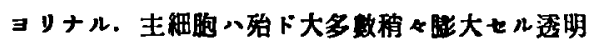

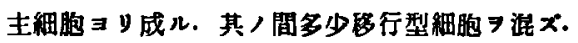

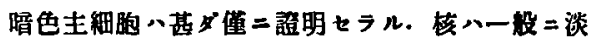

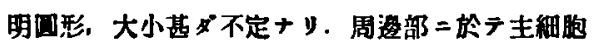

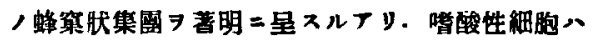

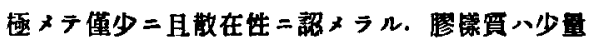
ニシラ主細胞閗二䐂メラル。
7. 第 31 侧 54 歲 男

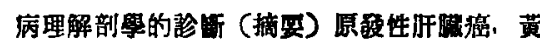
㡺

上皮小触所見 右上 $5.03 .01 .6 \mathrm{~mm} 14 \mathrm{mg}$ 右下 $4.82 .61 .0 \mathrm{~mm} 7 \mathrm{mg}$ 左上 $4.92 .81 .2 \mathrm{~mm} 8 \mathrm{mg}$

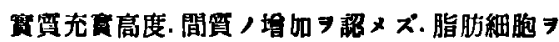

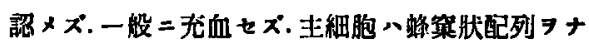

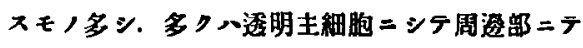

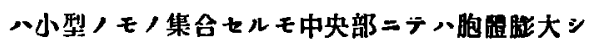

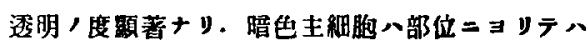

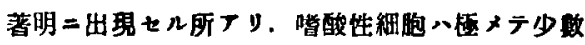

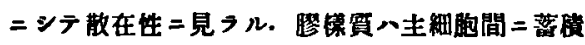
稍々著シキ所フリ概シテ「エォジン淡染性ナり。

\section{第2館 上皮小触所見概括}

1.大サ及ビ重量

旰政疾患例上皮小能”各例二於テ探取三得 タル數一定セズ，故二全能トシテハ單二最大 及ビ最重ノモノタ舉グルニ此ム。

第 2 表 旰践疾患全例所見表

\begin{tabular}{|c|c|c|c|c|c|c|c|c|c|c|c|c|}
\hline \multirow{3}{*}{$\begin{array}{l}\text { 们 } \\
\text { 㩆 }\end{array}$} & \multirow{3}{*}{ 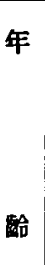 } & \multirow{3}{*}{ 性 } & \multirow{3}{*}{ 病 } & \multicolumn{2}{|r|}{ 上 } & 皮 & \multicolumn{3}{|c|}{ 小 } & \multicolumn{3}{|c|}{ 體 } \\
\hline & & & & \multirow[b]{2}{*}{ 轿 } & \multirow{2}{*}{$\begin{array}{c}\text { 最 } \\
\underset{(\mathbf{m m})}{\text { 大 }}\end{array}$} & \multirow{2}{*}{$\begin{array}{c}\text { 最 } \\
\text { 重 } \\
\text { (mg) }\end{array}$} & \multicolumn{2}{|c|}{ 主細胞 } & \multirow{2}{*}{$\begin{array}{l}\text { 譛 } \\
\text { 酸 } \\
\text { 性 } \\
\text { 細 } \\
\text { 胞 }\end{array}$} & \multirow{2}{*}{ 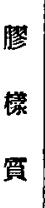 } & \multirow{2}{*}{$\begin{array}{l}\text { 結 } \\
\text { 締 } \\
\text { 織 } \\
\text { 坦 } \\
\text { 殖 }\end{array}$} & \multirow{2}{*}{ 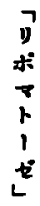 } \\
\hline & & & & & & & $\begin{array}{l}\text { 透 } \\
\text { 明 }\end{array}$ & $\begin{array}{l}\text { 唔 } \\
\text { 色 }\end{array}$ & & & & \\
\hline 1 & 32 & 女 & 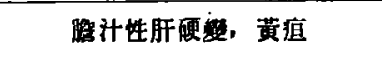 & 2 & $4.3: 3.2: 2.2$ & 20 & W & + & \pm & \pm & - & + \\
\hline 2 & 32 & 男 & \multirow{2}{*}{$\begin{array}{l}\text { 同上，觔石 } \\
\text { 同上，黃㡺，萎縮堅 }\end{array}$} & 2 & $7.8: 3.3: 1.0$ & 15 & $H$ & $H$ & + & \pm & - & + \\
\hline 3 & 39 & 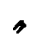 & & 4 & $7.3: 4.2: 2.3$ & 45 & 世 & + & $H$ & \pm & - & $H$ \\
\hline 4 & 40 & 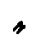 & 肝硬學 & 2 & $5.2: 1.7: 0.8$ & 6 & H & + & + & + & - & - \\
\hline 5 & 42 & 女 & 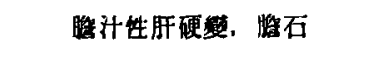 & 5 & $6.8: 4.6: 1.8$ & 28 & $H$ & $H$ & + & - & - & $H$ \\
\hline 6 & 43 & 男 & ラ氏訮硬唨 & 4 & $6.8: 3.0: 1.5$ & 19 & 世 & + & + & \pm & \pm & - \\
\hline 7 & 47 & 女 & 硬 & 2 & $5.5: 4.3: 23$ & 33 & H & + & $H$ & - & - & $H$ \\
\hline 8 & 47 & - & 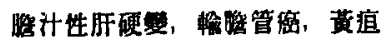 & 2 & $12.3: 5.0: 2.3$ & 83 & $H$ & \# & + & \pm & + & - \\
\hline
\end{tabular}




\begin{tabular}{|c|c|c|c|c|c|c|c|c|c|c|c|c|}
\hline \multirow{3}{*}{$\begin{array}{l}\text { 时 } \\
\\
0\end{array}$} & \multirow{3}{*}{$\begin{array}{l}\text { 年 } \\
2 \\
\text { 倍 }\end{array}$} & \multirow{3}{*}{ 性 } & \multirow{3}{*}{ 屚一名. } & \multicolumn{2}{|r|}{ 上 } & 皮 & \multicolumn{3}{|c|}{ 小 } & \multicolumn{3}{|c|}{ 骨柦 } \\
\hline & & & & \multirow[b]{2}{*}{ 數 } & \multirow{2}{*}{$\begin{array}{c}\text { 最 } \\
\underset{(m m)}{\text { 大 }}\end{array}$} & \multirow{2}{*}{$\begin{array}{c}\text { 最 } \\
\text { 重 } \\
\text { (mg) }\end{array}$} & \multicolumn{2}{|c|}{ 主細胞 } & \multirow{2}{*}{$\begin{array}{l}\text { 㫮 } \\
\text { 酸 } \\
\text { 性 } \\
\text { 細 } \\
\text { 胸 }\end{array}$} & \multirow{2}{*}{ 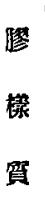 } & \multirow{2}{*}{$\begin{array}{l}\text { 結 } \\
\text { 絠 } \\
\text { 織 } \\
\text { 增 } \\
\text { 殖 }\end{array}$} & \multirow{2}{*}{ 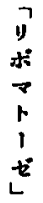 } \\
\hline & & & & & & & $\begin{array}{l}\text { 透 } \\
\text { 明 }\end{array}$ & $\begin{array}{l}\text { 暗 } \\
\text { 色 }\end{array}$ & & & & \\
\hline 9 & 51 & 女 & ～氏肝硬曼 & 1 & $6.5: 3.0: 1.0$ & 16 & $H$ & $H$ & + & - & 一 & + \\
\hline 10 & 51 & 男 & 䏩计性 肝硬最 & 3 & $5.0: 3.5: 2.2$ & 25 & $H$ & $H$ & + & \pm & \pm & + \\
\hline 11 & 52 & * & 訮硬 & 3 & $6.2: 3.2: 1.6$ & 29 & 世 & + & $H$ & + & $H$ & 一 \\
\hline 12 & 53 & * & 同 & 2 & $6.6: 2.0: 1.5$ & 11 & H & + & \pm & + & - & \pm \\
\hline 13 & 53 & $\Rightarrow$ & 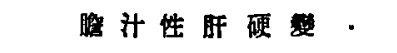 & 4 & $9.0: 3.1: 1.6$ & 34 & $\mathrm{HH}$ & + & + & \pm & \pm & + \\
\hline 14 & 55 & 女 & 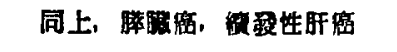 & 4 & $6.1: 3.1: 1.0$ & 9 & 册 & \pm & + & H & + & - \\
\hline 15 & 56 & 男 & 㭗 & 4 & $7.0: 2.2: 0.9$ & 20 & $H$ & $H$ & $H$ & + & - & + \\
\hline 16 & 59 & , & 同 & 2 & $6.3: 3.2: 2.3$ & 19 & 册 & \pm & \pm & + & - & - \\
\hline 17 & 63 & 女 & 腔计性肝硬篮，黃㡺 & 1 & $7.3: 3.2: 0.7$ & 9 & \pm & 册 & + & - & - & + \\
\hline 18 & 72 & 男 & ～氏 䀒硬量 & 3 & $8.3: 1.9: 1.1$ & 16 & $H$ & $H$ & \pm & + & + & 一 \\
\hline 19 & 33 & , & 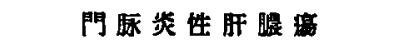 & 3 & $5.2: 3.2: 1.8$ & 12 & $H$ & $H$ & + & \pm & - & \pm \\
\hline 20 & 40 & 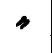 & 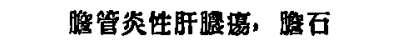 & 2 & $7.3: 4.4: 1.2$ & 19 & $H$ & $H$ & \pm & \pm & - & - \\
\hline 21 & 45 & , & 同 上, 同上 & 1 & $6.8: 2.2: 1.4$ & 14 & $H$ & $H$ & + & - & \pm & - \\
\hline 22 & 50 & ? & 同 上, 同上 & 4 & $7.7: 3.7: 1.9$ & 29 & W & $H$ & \pm & + & - & \pm \\
\hline $\mathbf{2 3}$ & 35 & 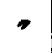 & 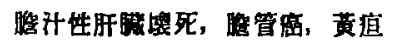 & 2 & $5.1: 4.5: 2.1$ & 16 & $H$ & $H$ & + & $H$ & + & - \\
\hline 24 & 57 & ? & 上, 同上 & 2 & $7.0: 3.7: 1.3$ & 21 & $H$ & $H$ & + & + & - & 一 \\
\hline 25 & 35 & 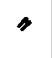 & 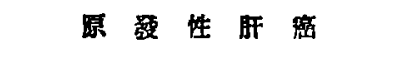 & 3 & $7.1: 3.8: 1.9$ & 35 & + & HH & + & - & + & 一 \\
\hline 26 & 37 & $\Rightarrow$ & 同 上, 苖疸 & 4 & $9.6: 3.3: 1.9$ & 39 & $H$ & $H$ & + & + & - & + \\
\hline 27 & 40 & 男 & 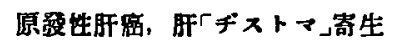 & 1 & $8.5: 2.0: 1.3$ & 15 & 册 & \pm & \pm & + & - & - \\
\hline 28 & 46 & $\leadsto$ & 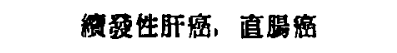 & 1 & $6.7: 2.0: 1.5$ & 11 & H & + & + & \pm & + & - \\
\hline 29 & 48 & 女 & 上, 脽震 & 4 & $8.0: 3.2: 2.0$ & 22 & + & H & H & \pm & + & 一 \\
\hline 30 & 53 & 男 & 上. 胃 櫐 & 4 & $8.5: 3.0: 1.1$ & 18 & + & H & $H$ & + & $H$ & 一 \\
\hline 31 & 54 & , & 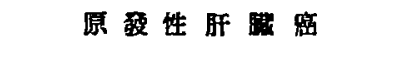 & 3 & $5.0: 3.0: 1.6$ & 14 & 世 & + & + & $H$ & - & - \\
\hline 32 & 56 & $s$ & 同上，肝「ヂストマ」奇生 & 3 & $5.0: 2.7: 1.0$ & 11 & + & W & + & $H$ & $H$ & - \\
\hline 33 & 58 & , & 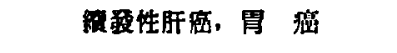 & 3 & $5.9: 3.0: 1.2$ & 18 & $H$ & $H$ & + & + & $H$ & - \\
\hline $3 t$ & 73 & 女 & 同 上，同上 & 4 & $8.9: 2.4: 1.3$ & 25 & H & + & $H$ & \pm & - & + \\
\hline 35 & 60 & 男 & 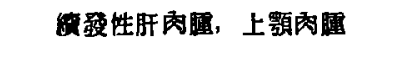 & 3 & $8.5: 4.2: 1.0$ & 24 & H & + & + & + & - & - \\
\hline & & & 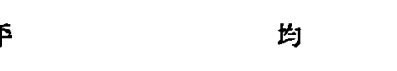 & & $7.0: 3.2: 1.5$ & 22.3 & & & & & & \\
\hline
\end{tabular}




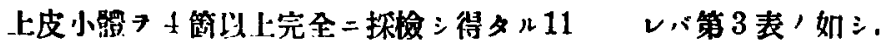

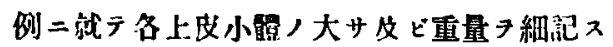

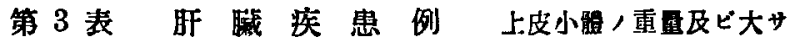

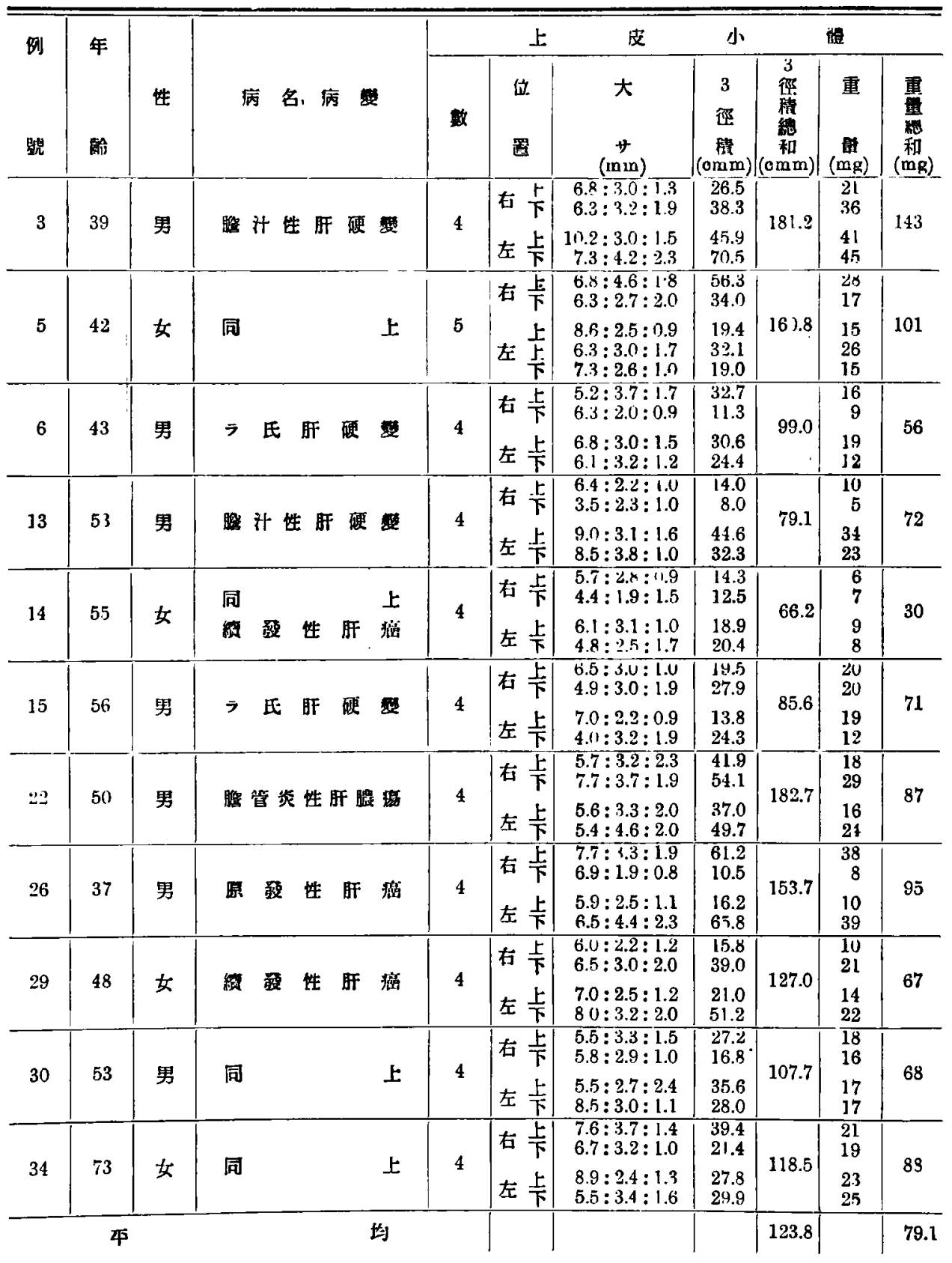


即千各例二於々ル上皮小體ノ重量總和ノ本 均八 $79.1 \mathrm{mg}$ ニシテ, 3 徑厮總和，年均八 $123.8 \mathrm{cmm}+\nu$.

\section{2. 組絨㐿的所見}

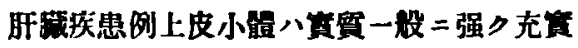
シ，大多數入例ニアリテハ殆ド間貿ノ坦加七

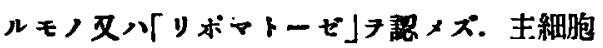
八全测通ジ透明主細咆ノ出現著シク之二反 三晤色主細胞ノ出現八比筇的少數ナル傾向 示七り。郎手全例中透明主細咆，出現力極 テ高度ニシテ殆ド全上皮小體ヨ占ム䨳アルモ ， 3 例，透明主細胞，仙現力高度ナルモノ13 例, 透明主細泡ノ出現が中等度ナルモノ 13 例 透明主細胞ノ出現が少量ノモノ5 㫜，透明主 細胞ノ出現か極メテ微量ナルモノ1例ナり。 而三テ肝僦疾患中透明主細胞卜晤色主細胞 八量的比校フ見ル二透明主細咆カ暗色主細胞 フ淩駕スルモノ八旰䂠戀二於テ晨モ多ク, 肝

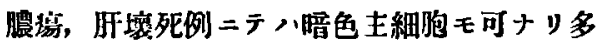

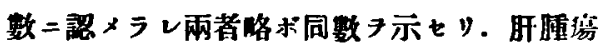

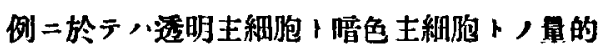

\section{第 5 龺}

肝疾患例说二数照例(第 1 報第 3 章參照)， 士波小體所見 $\rightarrow$ 比较スル二各例二於rル全上 皮小體，重皇合計，本均，對照例， $67.0 \mathrm{mg}$

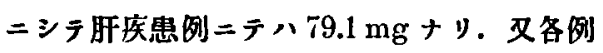

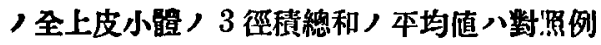
ニテハ100.6ナル二肝疾患例ニテハ $123.8 \mathrm{cmm}$

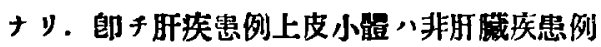

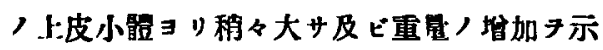

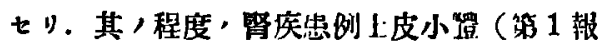
參照）二比スレバ稍々輕微ナルモ，其ノ組緎
差供售シキモノ多ク，或ルモノ二於テ，特二 透明主細咆多ク又成ルモノ二於テ八特二暗色

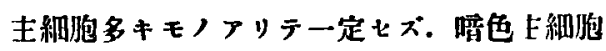

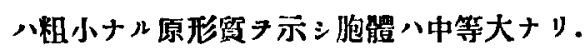
透明主細胞八胞喳中等大ナルモ時トシテ著シ ク膨大シ甚シキ場合二ハ 2,3 八細胞か境界不 解明トナリ互二癒合七ルガ如キ觀尹示スモ， フリ. 內容心水绿透明ニシテ其ノ間微細ナル 絲狀糊梁及ビ僅少ノ顆粒フ證明ス。核八中心

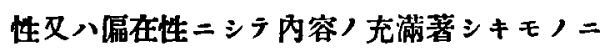
於テハ浱䋧狀き示スモノフリ．部位ニヨリテ 八之等主細胞八結節狀集團 來セル所アリ．又少數ノ細胞集マリラ蜂䓨狀 及ハ「ゼッテン狀ノ構造き示スモノァリ。 啫酸性細胞，過牛例二於テ出現スルモ極， テ僅少ニシテ散在性二認メラルルニ過ギズ.

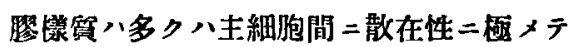
微二認メラルル二過ギザルモ，第 14 例二於テ

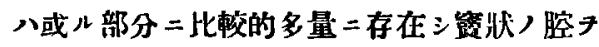
形成三，甲狀腺，墟胞二見ラルルガ如キ多數 八空匏形成ヨ体フモノフリ。

\section{總括及と考按}

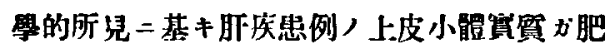

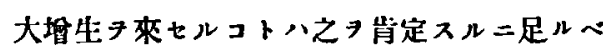
¿.

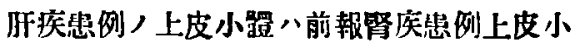

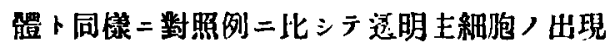

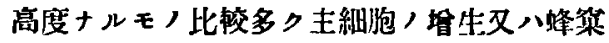

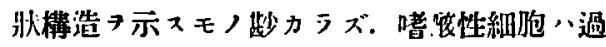

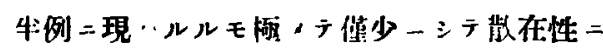

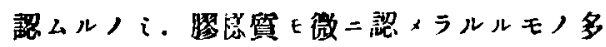
¿. 
以上ノ所見二微スル二上皮小體八肝疾费， 際ニモ展々一定，形態祭的委化 ニシテ筫細炮就中主勫胞，坦生站二透明E 細绚, 高度+ル圳現 7 活有, 所見トスルモ， ナリ.

文斯二徽スル二䀒疾患又心旰機能障得フル

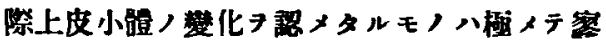
客タルモノニテ Dietrich 八略汁度フ形成七

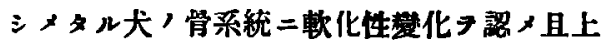

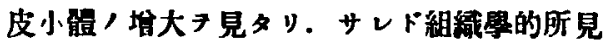

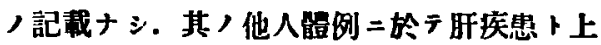

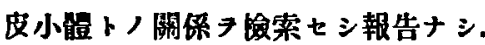

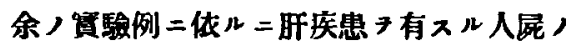

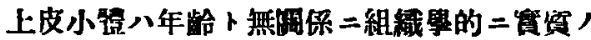
充居フ來シ一般二透明主細咆，高度ナル出摬 フリ而シテ斯ノ如キ所見が上皮小管，機能立 進狀態タ表示スルコトハ已二第 1 郝二詥ゼル 如クニシテ節チ余八由是朋疾腎二際シ展々上 皮小體㙨能方進狀態，存在スベキコトタ主張 ヒントスルモノナリ.

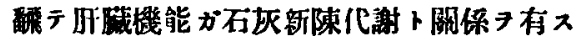
ルコトハ請家，報告粆カフズ． 即手 Zimmerman, Berncsy 等”璌疸患者二於亏血中 $\mathrm{Ca}$ 量/减少セルコト尹述べ, King and Stewart

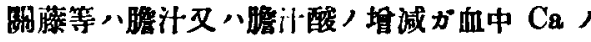
㘿減子來ス卜言七。Askanazy, Goldschmidt

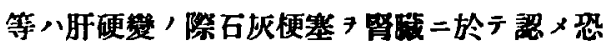

\section{第 6 章}

1）旰臟矣患例，上皮小體八大サ，重量共 二稍々著シク坦加入。

2）肝矣必例，上皮小體二於テ八透明主 緗胞，出現智著ナリ。

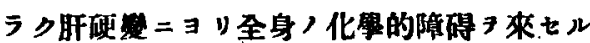

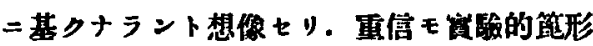

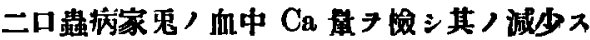

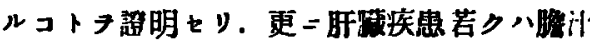

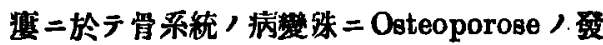
現キ見ルコトハPawlaw, Seidel, Gillent, Gottes, Buchbinder u. Kerns, 馬昜等 $=\exists$

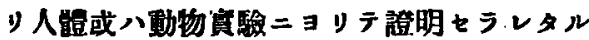

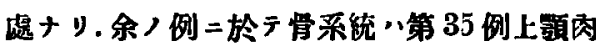
脏ニヨリ骨組䄉ノ侵サレタルョ見タルノ外肉 眼的二買狀ナク又助骨所見二變化 7 認メザリ キ.

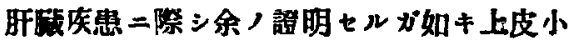
體，態度か如何ナル理山二ヨリ招來七ラルル ヤ二就キテ八尚木今後ノ研究二侯ツべキモ肝

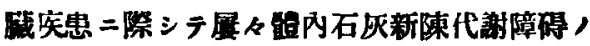
存在スベキ八敍上ノ文跃二徽シテモ碰的; 得

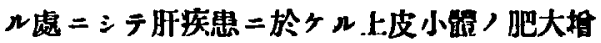
化乃至践能六進世變化八恐ラク前記ノ如キ石

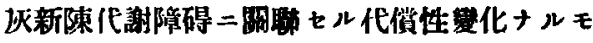

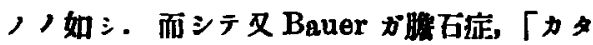

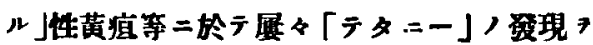

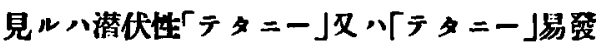
狀態，存在二因ルト言へル二徽スルモ訮疾患

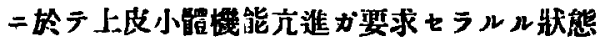
ニヌルベキコトハ容易二首肯シ得ルトコロナ リトス.

結 論

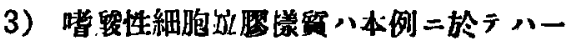
定，阙保习琶メズ。

4）肝睡疾患例，上皮小體 “機能六進狀照 ニフィモノ多シ. 
相 原 諞 文 附 圖

芽 1 目

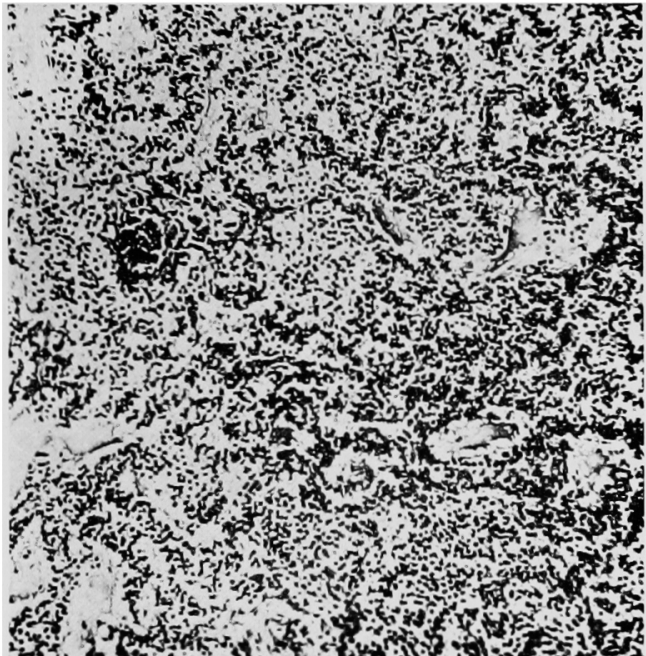

$$
\text { 第 } 33 \text { 圆 }
$$

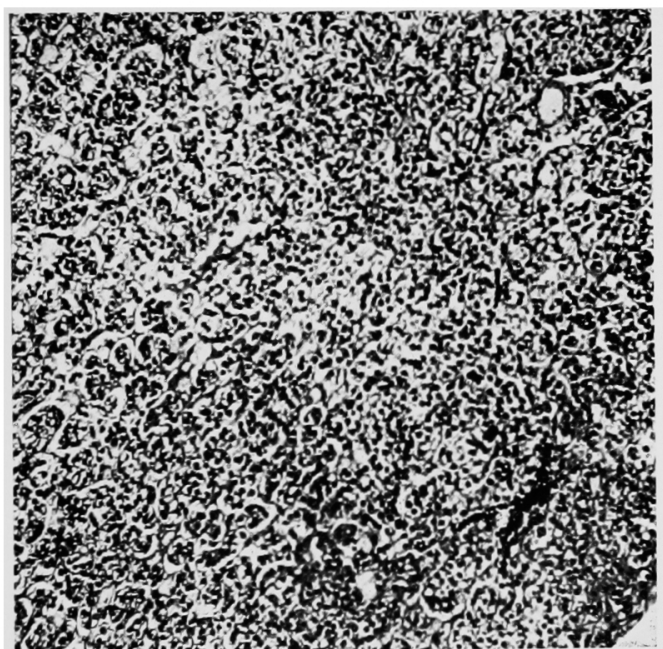

第 5 圖

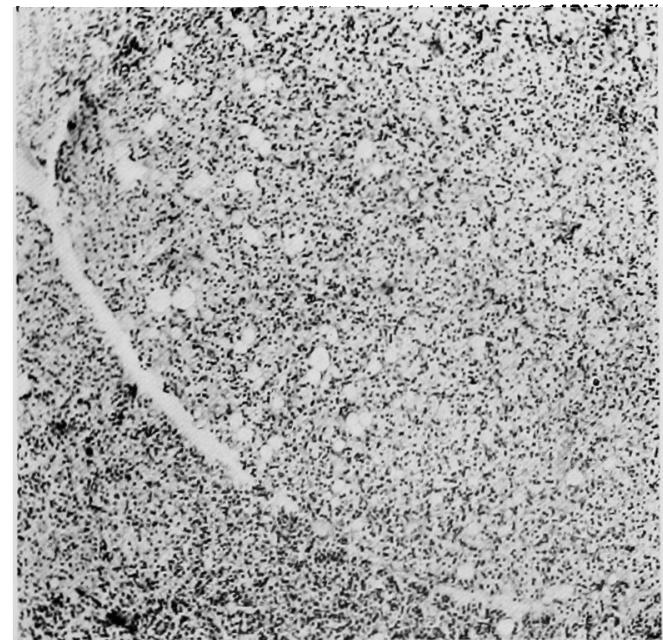

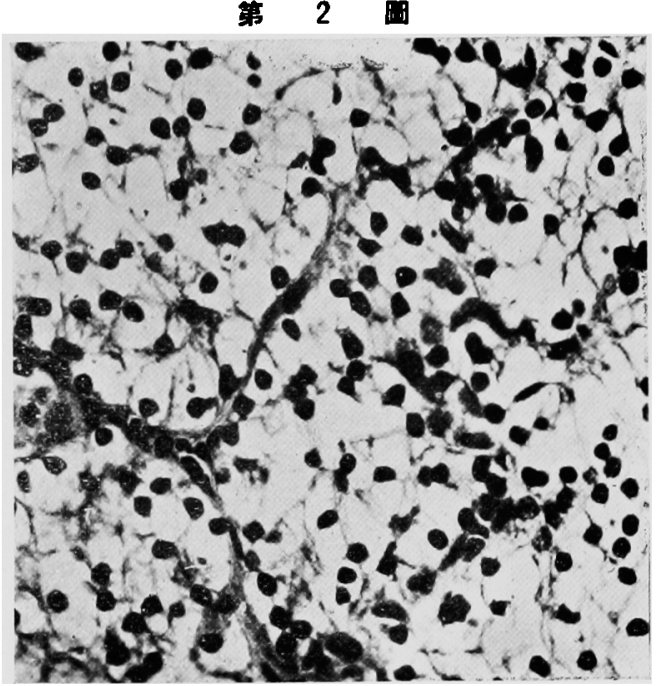

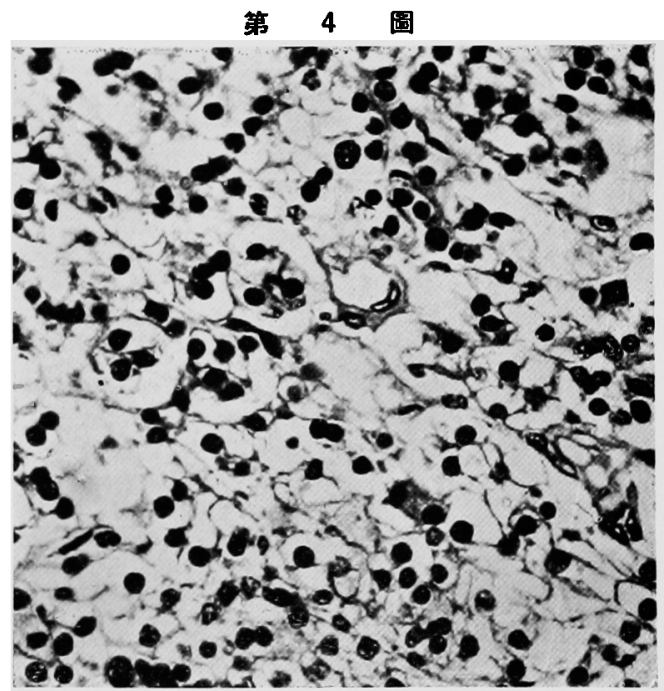

\section{第 6 圖}

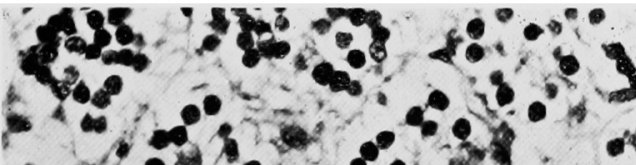

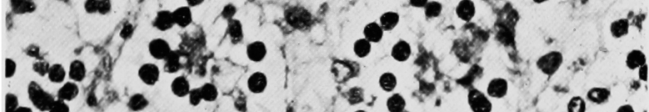
$35^{3} 0^{\circ} 0^{\circ} 0^{\circ}$ b. 0 a - il ${ }^{\circ}$ of

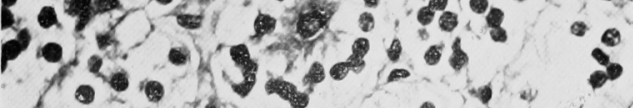

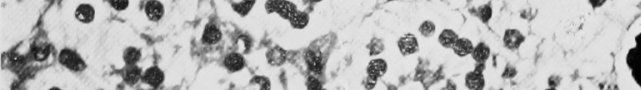
2.

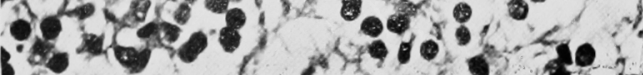




\section{文}

1) Asher, HB. d. Inmeren Sekretion. Bd. 2, 8. 263. 2) Aiberioni, zit. n. Hexheimer. G. 3) Askanazy, zit. N. Goldschmidt. 4) Baver, Innece Sekretion. S. 268, 1927. 5) Berencsy, Kl. W. Nr. 26, 8. 1213, 1929. 6) 'Berblinger, V. A. Bd. 275, S. 230,1930 . 7) Buchbinder \& Kem, Arob. of intern. Med. Vol. 40, 1927. 8) Biedl, Innere Sekretion. 9) Blum, Studien über die Epithelkörperchen 1925. 10) Blum, Weitere Studien über die EPK. 1927. (11) Carlson \& Jacobson, Amer. Joum. of Physiol. 25, and. 28. 12) Capobiano u. Mazziolti, zit. nnch Biedl. 13) Delitala, zit. nuoh. Biedl. 14) Danish, Frankf. Zeits. Bd. 32, S. 188, 1925. 15) Dietrich, Bruns Reitr. Kl. Chirur. Bd. J31, 1927. 16) Gold, Mitt. n. d. Grenzg. d. Med. u. Chir. Bd. 41, S. 63, 1928. 17) Goettche, Monats. f. Kindb. Bd. 35, 1927. 18) Goldschmedl, Beitr. z. puth. Anat. n. z. allg. Puthol. Bd. 56, S. 77, 1913. 19) Gillert, Zeits. f. d. ges. exp. Med. Bd. 43,1924 . 20) Greenwald, Journ. of biol. chem. Vol. 14, P. $\left.36^{\circ}, 1913 . \quad 21\right)$ Gosii, zit. nucl. Biedl. 22) Goะzi, Intern. Monuts. f. Anat. u. Physiol. Bd. 29. s. $273 . \quad 23)$ Harier, zit. nach Biedl. 24) Hexheimer, G., is

HB. d. speo. path. Annt. I. Histl. Bd. 8, 1926. 25) King "t. Stezunt, Journ. of exp. Med. Vol. 11, P. 673, 1909. 26) Kerl, D. M. W.No. 31, s. 1271, 1925. 27) Klinke, Ergebn. d. Physiol. Bd. 26, 1928. 28) Morel et Rathery, zit. Dnoh Bied]. 29) Medwedew, Zeits. f. Physiol. Obem. Bत. 72, S. 410, 1911. 30) Oppel, Endokrinolngie. Bd. 6, S. 11, 1930. 31) Pawlow, zit. nach Babn. 32) Sloland, The Amer. Journ. of Physiol. Vol. 33, P. 383, 1914 . 33) Ssamarin, V. A. Bd. 269 , S. 536, 1928. 34) Seldel, zit. nuch Babn. 35) Tomaszewski, Frankf. Zeits. Bd. 21, S. 38, 1918. 36) Underhill \& Blatherwick, Journ. of biol. chem. Vol. 18, P. 87, 1914. 37) Wesselkin, Ssazvitsch a. Ssudakawa, Berichte d. ges. Physiol. Bd. 29, S. 776, 1924. 38) Winierberg, zit. moh Biedl. 39) Zanfrognini, zit. nach Biedl. 40) Zimmermann, Kl. W. Nr. 16. S. 726, 1927. 41) 金明學, 朝鮮祭學, 第19究, 8號。(1), (2). 42)

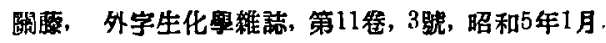
43）重房，肉山嗯學，第44年，第4號，炤和6年4月 44）馬嚗, 日新基、第20年、第8號、昭和6年4月. 45）原, 事公論, 1031, 昭和7年4月23日.

\section{附圖說 明}

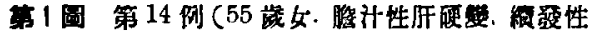
朋的箈)

上皮小暍 (Zeiss $7 \times 10)$

唀明主細胞 (卅)

韻色主細胞（士）

第 2 回上 (Zeiss $7 \times 40)$

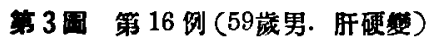

上皮小體 (Zeiss $7 \times 10)$

透明主細胞 (卅)

暗色主細胞 ( \pm )

34日同上 (Zeiss $7 \times 40)$
}

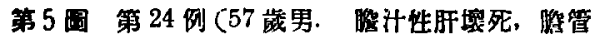
㢈)

上皮小體 (Zeiss $7 \times 10$ )

透明圭細胞, 結節狀增部 (十)

第6圖同上 (Zeiss $7 \times 40)$

透明主細胞 ハ「ロゼッテン」形成 